\title{
An other-typological illustration of the Exodus story according to Dr King's perception of universal reconciliation in his sermon on Exodus 14:30
}

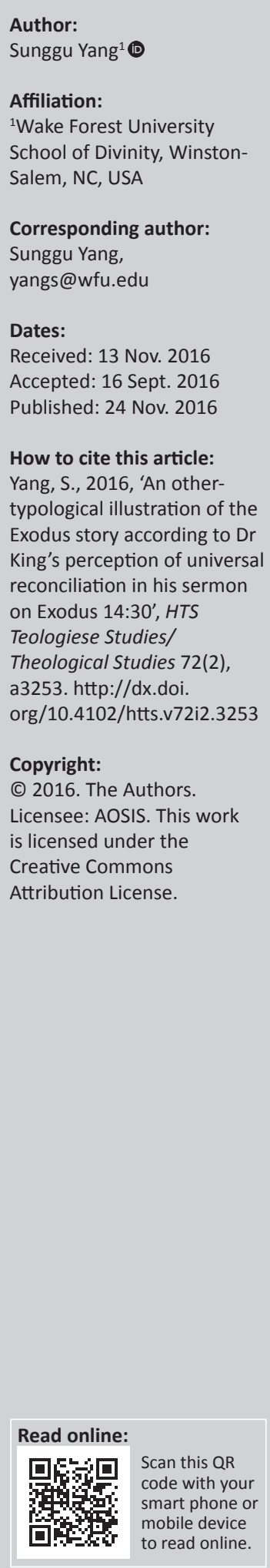

The article contends that Dr King makes an other-typological illustrative use of the Exodus story in his preaching - one of the most significant biblical narratives that the Black church in the US holds dear. This peculiar use of the Exodus story differentiates itself from the conventional typological understanding and use of the same story in the Black church's history. While in the latter the Exodus story has a symbolic meaning of the irreconcilable conflict between the oppressed and the oppressing reality, in the former the same story contains a spiritual lesson that what is really hoped for in the midst of the seemingly irreconcilable racial and social conflict is compassion, liberation, and reconciliation for both parties involved. This article, by examining a representative sermon of Dr King on the Exodus story, shows that his other-typological illustrative approach originates from his fundamental theological ideal of universal reconciliation.

Let us remember that as we struggle against Egypt, we must have love ... (King 1992:III, 261)

\section{Introduction}

This article investigates Dr Martin Luther King's illustrative understanding of the Exodus story in his sermon on Exodus 14:30, which is in stark contrast to the Black church's widely accepted typological understanding of the same story (Raboteau 1995). ${ }^{1}$ As we shall see, however, King's illustrative use of the Exodus story is not 'pure' but blends both typology and illustration. King, indeed, initially embarks on the different-typological or other-typological understanding of the same Exodus story and eventually ends up using that story as a crucial illustration of his sermon point. We shall see that all this discussion of typology and illustration is not simply a matter of a different approach to the same story and its same literary-theological meaning but a significant matter of a different theological understanding of God, humanity, evil and eschatological ethics, as well as a different literary perception of the Exodus story.

This article first provides brief definitions of literary typology and sermon illustrations as the critical guide or foundation for the discussion to come. With those definitions in hand, the article then examines how the North American Black church throughout its ecclesial tradition often has understood the Exodus story in a typological sense for the church's own historical and theological merits. ${ }^{2}$ In particular, our focus will be on how Black preachers have explicitly demonstrated this typological understanding of the story in their sermons on Exodus, especially for its relevance to Black freedom and liberation. For this part of the article, I owe a significant investigative debt to Raboteau's (1995) historical examination of the typological understanding of the Exodus story in the Black church and LaRue's (1999) survey of Black church sermons of the 19th and 20th centuries.

My article then explores how King demonstrates his unique other-typological understanding of the Exodus story, rather than the traditional one. This in turn leads us to see how King adopts the story as an illustration at a particular point of his sermon based on his particular perception of the Exodus narrative.

1.In particular, in chapter two Raboteau recognises that from early on in Black Christianity, Israel's Exodus story became a 'Black Exodus' story of 'Black Israel' in almost a literal sense; White America or the new Pharaoh's Egypt was now doomed and would soon literally be crushed by the mighty God. As we will discuss later, however, this literal sense has been weakened since then and has indeed been replaced by a spiritual or metaphoric sense.

2.Black churches are found around the world including Latin America, Africa, Europe, etc. Each of these has particular a historical background and a particular theological nuance, although they also share certain commonalities. Given the time and space limit, this paper covers only the North American Black church context where Dr King's theology was born and active. 
The last portion of the article closely examines King's illustrative use of the Exodus story in the sermon on Exodus 14:30 anchored in his theological worldview of reconciliation. As we shall see, his particular use of the Exodus story and his theology of reconciliation are symbiotically inseparable. Thanks to the illustrative understanding of the Exodus story, King was able to find a firm theological ground to depict the God of reconciliation, while the reconciliatory notion of God that the illustration presents meshed precisely with the theological hermeneutic that he initially brought to the Exodus text itself.

Yet, by no means, do I suggest that this narrow investigation based on only one sermon of King's on Exodus can or does completely explain King's sophisticated other-typological or illustrative use of the Exodus story and related complex theological ideas that his other sermons and public speeches demonstrate. Such a task would certainly require volumes of work. Nonetheless, I hope that this research on the Black church's, and definitely King's, most significant biblical narrative for its or his faith, will shed an important interpretative light on King's preaching and his theological worldview, because it is based on this narrative that the Black church's very theological identity has been built from its American inception (Mays 1969:19ff).

\section{Definitions: Typology and illustration \\ Typology}

At this point, we need to clarify certain definitions of typology and illustration as they are the key terms in this article and understanding them correctly, or at best sharing the same definitions, will reduce the risk of misunderstanding the same subjects to come.

\section{The Cambridge Dictionary of Christianity defines 'typology' as:}

a method of interpreting Scripture in which it is assumed that events, institutions, and persons in the OT ('type') foreshadow events, institutions, and persons in the NT, and/or such features of both the OT and the NT foreshadow events, institutions, and persons in the time of the interpreter. (Patte 2010:946)

What is particularly important for us in the definition is that through the biblical or theological process of typology, people find certain typological counter features of the present (they believe) prefigured in the Old Testament and/or the New Testament. In short, what happened before happens here and now just as it was.

Yet, of course, there cannot be a literal one-to-one-match type of event between what happened before and what is happening now. For instance, when people in the Black church tradition typically interpret the old Exodus story as the anti-type of their modern slavery liberation movement, such Exodus narrative features as the Red Sea, the Pharaoh, the promised land, the manna, and so on, cannot literally match what the Black people have gone through; it can only can match their experience typologically (e.g. the Black slaves confronted the white masters, but not 'modern Pharaoh' in a literal sense). ${ }^{3}$

Furthermore, and more important for this article, interpretative meanings of the same typological story can vary considerably depending on key contemporary typological counterparts that the present reader chooses to bring to the original features. For instance, as we shall see later in King's case, when King holds up the universal American social ills or evils as the typological counterpart of slavery in Egypt vis-à-vis White America that the Black tradition has often perceived as the real typological Egyptian enemy, King's interpretive meaning of the same story is thoroughly different from the latter.

\section{Illustration}

According to Long (1989:200), from approximately the 19th century, there have been two major homiletic streams in understanding an important preaching element, or illustration, the second stream being more contemporary. The first somehow pragmatic stream understands illustrations as 'windows on the word' that provide the clarification of logical sermonic concepts. In other words, the sermon will use the illustrations in order to 'make the [sermon's] message clear' (Sanster 1954:206), ${ }^{4}$ 'to make the truth concrete' (Jones 1956:137), and eventually 'to help the congregation understand' (Sweazey 1976:193) the main ideas of the sermon. Long argues that the use of this utilitarian trend of illustration is widely accepted when and where the sermon is 'supposed to develop a "thesis," and illustrations [are] seen as devices designed to illumine and clarify that thesis' (Long 1989:211).

The second stream which Long strongly advocates perceives illustrations as the literary homiletic sinews. At times, it is so interwoven into the sermon that as Craddock (1985:204; italics mine) argues, 'In good preaching what is referred to as illustrations are, in fact, stories or anecdotes which do not illustrate the point; rather they are the point'. Craddock continues that 'a story may carry in its bosom the whole message'. Long (1989:203) contends that this trend of illustration use has become popular recently, the understanding of the sermon being the 'integrated act of communication'. In the integrated sermonic act of communication, each part of the sermon, including the illustrations, works together to achieve one communicational purpose. Illustrations, thus, are not mere 'windows' to assist other important parts but are the important parts themselves.

This article deliberately takes the first understanding of illustrations understanding as the main domain for the rest of

3.It should be noted that this sort of typological reading of the Exodus story was not a 'new invention' by the North American Black church, but that it had certain precedents in different parts of the world. For instance, the Boers (and certainly a good number of Blacks in South Africa) held the Exodus narrative as their primary good number of Blacks in South Africa) held the Exodus narrative as their primary source of inspiration, based on which they made their own 'Exodus' to eastern and north-eastern areas of South Africa. In the case of the Boers, their interpretation and action were more literally applied, although still in a typological sense. See
Robin Binckes (2013).

4.In the Black church traditions, the homiletic practice of using illustrations that make 'the message clear' is widely known and often utilised. See Mitchell (1990; esp., chap 4); Cone (2000; esp., chap. 3), Proctor (1994; chap. 4) and others. 
the article, not because the former is more appropriate or important in preaching in general, but only because the sermon in focus that we will investigate in sections to follow operates in that first sense and uses illustrations accordingly.

\section{Typology: God only on one side}

From the embryonic stage of Black Christianity in America, Black Christians have often identified themselves with the old Israel. ${ }^{5}$ That is, just as the old Israel in the power of YHWH-God had broken the bondage of Egypt and marched towards the Promised Land. Christian slaves believed that they would also break the enslaving yoke of the new Egypt and march towards the new Promised Land (Raboteau 1995:28). ${ }^{6}$ What was for them the new evil Egypt was none other than White America where the salve owner trod upon their most basic rights of life. In that lifeless circumstance, just like the children of Israel, they pursued and proclaimed their freedom and liberation against White America, their evil enemy. A God of power and ultimate good would support and guide this new Black Israel's struggle on the triumphal march into the new promised America. Definitely, in this new version of the same Exodus story, God is only on their side against the evil other.

The Black preachers who came out of the same experience of the White American slavery were the avant-garde of that new Black Israel's struggle against the new American Pharaoh's slave regime. They also firmly believed in the same typological narrative that God would take their side only against the evil counterpart even to the extent that God would help them defeat and utterly crush the latter. The same Exodus story of the Bible had to be achieved here and now in the new typological American history.

Francis J. Grimke (1850-1937), who was once regarded as one of most influential Black preachers of his era (LaRue 1999:46) and helped found the NAACP, ${ }^{7}$ is a good example of a person who took this kind of typological understanding of the Exodus story and preached accordingly. In a sermon on Exodus 1:9-10 entitled:

A Resemblance and a Contrast between the American Negro and the Children of Israel, in Egypt, or the Duty of the Negro to Contend Earnestly for his Rights Guaranteed under the Constitution

5. Note that by Black Christianity i do not mean one homogenous group of Black Christians. Like any other racial-ethnic churches in the US (including Euro-American churches), various denominational branches have existed in the Black church from the beginning, and have demonstrated different theological or spiritual themes and emphases, even regarding the idea of the 'old Israel'. Cf. footnote 9. Also, refer to Lincoln and Mamiya (1990; esp., chaps 2-4). Lincoln and Mamiya in their book introduce seven historical Black denominations, which include the African American Methodist Episcopal Church (A.M.E.), the African Methodist Episcopal Zion church (A.M.E.Z.), the Christian Methodist Episcopal (C.M.E.), the National Baptis Convention, USA, Incorporated (NBC), the National Baptist Convention of America, Unincorporated (NBCA), the Progressive National Baptist Convention (PNBC), the Church of God in Christ (COGIC).

6.Of course, as Raboteau recognises throughout the book, today's Black Christianity, more or less since the Civil Rights movements of the 1960s, identifies itself less with the old Israel than their 18th- and 19th-century counterpart did, as since Black Christians no longer live in the old slave market era. Yet, the same 'Black Exodus' motif still remains in the Black church's 'bones' and often becomes a central subject of Black preaching today because the ongoing racial discrimination, implicit or
explicit, is considered the extension of the old Black slavery era.

7.NAACP stands for National Association for the Advancement of Colored People, the non-profit organisation whose Atlanta branch King's father headed and which King joined in the late ' 50 s and in which he once had an influential role.

\section{Grimke preached:}

When the children of Israel first went down into Egypt it was with no intention of remaining there permanently ... Nor was it in accordance with the divine plan that they should remain permanently, as is evident from the record, in forty-six of Genesis. 'And God spake into Israel in the vision of the night, and said, Jacob, Jacob ... fear not to go down into Egypt, for I will there make of thee a great nation: I will go down with thee into Egypt, and I will surely bring thee up again'. God is not dead - nor is He an indifferent onlooker at what is going on in this world ... If some Moses should rise up today, as of old, and say to this nation, as was said to Pharaoh, 'Let my people go' ... I believe from every part of the land - North, South, East, and West, there would be but one voice, and that would be, Let them go ... One day He will make requisition for blood; He will call the oppressors to account ... If we are true to ourselves and to God the victory will be ours. (Woodson 1942:I;348-356)

As is explicit in this passage, the preacher demonstrates several typological understandings of both the Exodus story and Black Christians. Firstly, Black Christians are chosen people just as the people of Jacob were chosen by the sovereign God. Secondly, God is mighty enough to deliver them from the current bondage of slavery just as the God of Exodus did for the Israelites. Thirdly, the Black people, just as the Israelites, must be the ultimate victors of this struggle against the ruthless oppressors of slavery. Finally, God's judgment is definitely coming just as it did for the old Israel. In short, the old familiar Exodus story becomes exactly the Black people's own storytold. The old Israel's Exodus story has become the Black Exodus story.

What this typological understanding of the story eventually leads Black Christianity to is the celebration of liberation of the oppressed, along with a story in which God is on their side. Of course, as God is the God of the whole creation, the evil oppressors also exist in the realm of God's sovereign reign of the universe and have a chance to be included into the good side of the oppressed as well. Yet still, as long as their evil conduct goes on and they do not repent, they have no chance to be included in God's new Promised Land, but only have the fate of dying on the seashore. Nor are the liberated Black people supposed to have compassion on and love for their resisting, stiff-necked enemies who have been just doomed to death, as a Black slave woman from the late 19th-century America prays in a somehow 'bloody' outcry:

Thar's day a comin'! Thar's a comin ... I hear de rumblin' ob de chariots! I see de flashin' ob de guns! White folks' blood is a runnin' on de ground like a riber, an' de dead's heaped up dat high! ... Oh, Lor'! hasten de day when de blows, an' de bruises, an' de aches, an' de pains, shall come to de white folks, an' de buzzards shall eat 'em as dey's dead in de streets. Oh, Lor'! roll on de chariots, an' gib de Black people rest an' peace. (Livermore 1888:260-261)

As the prayer goes, the ultimate celebration belongs only to the Black people, whereas 'white folks' are utterly doomed. Yet, there is still a chance for oppressors to repent, return and thus enjoy God's salvation alongside the currently oppressed Blacks. However, the 'chance' will not last forever. Repentance 
is an urgent matter. (Later as we shall see, the primary task of repentance gives way to the more foundational matter of exorcising evil in King's theology).

In sum, the traditional, ${ }^{8}$ typological understanding of the Exodus story explicitly divides two sides between the good oppressed people and evil oppressors (meaning specifically, White America) and describes God only as a God of the oppressed..$^{9}$ Obviously, this God of the oppressed is the God of retributive justice who is willing to defeat and even crush the enemies of the oppressed 'at the seashore'. This same God would stand and work with the Black Christianity formed deep in the Black consciousness of the typological narrative, for the grand moment of final freedom and liberation of enslaved Black people; in the conventional Black Exodus narrative, therefore, there is no grand anticipation of potential reconciliation between the two opposing sides, unless there is repentance first on the side of the oppressors..$^{10}$

\section{Other-typology: God on both sides}

It is very likely that King had fully recognised the traditional typological understanding of the Exodus story of the Black church as he grew up in the typical Black Baptist church where the dramatic story of the prophet-liberator Moses was told as one of the central prophetic identities of the Black preacher. ${ }^{11}$ King himself kept this prophet-Moses image as one of his prominent personas, and it was the one he used effectively for his public ministry (Lischer 1995:174-75;225).

Thus, it is no wonder that in his sermon on Exodus 14:30, delivered at the Cathedral of St. John the Divine in New York on 17 May 1956, King seems at first to follow well the typological narrative ethos and pathos of the Exodus story. He tells us in the middle of the sermon that the evils of segregation, oppression and colonialism that the Black people are now facing are the same evils that Egypt and its Pharaoh symbolised and imposed on the old Hebraic people.

8.From this point on, when my article uses the phrase 'traditional understanding' 'typical understanding' of the Exodus story, I will mean only that this typological understanding has been widely accepted in the Black church from the church's very inception in America, as Mays (1969) notes in his book The Negro's God. As Mays also notes, and as will be discussed further below, this does not mean that all Black Christians have shared this traditional or typical understanding.

9.In an intercultural comparative sense, it is interesting to know that during apartheid in South Africa, white Afrikaners believed and even preached the theological idea of 'God is for us'. According to Johan Cilliers (2006:1-5), they identified themselves as ancient Israel in a typological sense. Much as God defended Israel and fought against all nations that attacked Israel, white Afrikaner preachers preached that God would defend them and fight against rebellious Blacks. In this instance, God 'belongs to' only one (white) side.

10.As mentioned in passing above, not all Black Christians have claimed the typological story of Exodus and thus the typological narrative identity in faith, namely 'Godstory of Exodus and thus the typological narrative identity in faith, namely 'Godwith-only-us' faith. Indeed, over the course of Black church history, there have
been a considerable number of Black churches that did not express this been a considerable number of Black churches that did not express this
dichotomous understanding of God and the world, and instead took an accommodationist position, either voluntarily or as result of the brainwashing of slavery, instead accepting a 'God-with-them-as well' type of faith. Baer and Singer (2002: Chaps. One and Two) make this point as well, even though their focus is not on the typological narrative understanding of the Black church itself. According to them, this somehow compromised, but not necessarily reconciliatory, sociotheological position of the Black church already appeared early in the Black church's inception, although it was much weaker at that time. Eventually, this second position grew stronger, and even though it remained the minority position in the position grew stronger, and even though it remained the minority position in the Black church, it was particularly influenced by advanced industrial capitalism from the late 19th century on. Thus, at this point it suffices to recall that not al Black church branches have a typological narrative identity of 'God-with-only-us'
faith based on the Exodus story.

11.During the interview with Lischer (1995:173), a retired beautician and member of Ebenezer still referred to King to as 'a Moses to the Black race'.
And just as the evil of the slavery-obsessed Pharaoh died at the seashore, we are now also gradually seeing the death of the evil of segregation and oppression in the sheer dawn of freedom and justice. At this point, therefore, it seems that King adroitly pictures the current social situation of the Black people in a typological sense; that is, the Black people's liberation story is equivalent to the Exodus liberation story.

Yet, we notice that already King's typological interpretation of the Exodus story above has subtly broken away from the Black church's typical typological understanding of the same story, although his sermon still goes on in the similar typological narrative form and tone. Unlike the traditional typological perception, King here does not equate the evils of Egypt or Pharaoh with the White America itself. Rather, he uses those anti-types of evil to designate bigger or universal American social problems that the Black people are now confronting; segregation, oppression, colonialism and so on. Broadening the 'face of the enemy' from the White America to the American social ills (or evils), although it seems to be a little thing, makes a huge difference in the typological understanding of the Exodus narrative. In this new typological understanding, the White America would no longer be the enemy to be crushed as traditionally understood. Rather, as his sermon later insists, they can be reconciled and included into the good side of God. At this point, therefore, we see a new, different typological understanding of the Exodus story start to emerge in King's sermon.

Approaching the end of the sermon, King suddenly and, this time, explicitly again breaks from the traditional, typological understanding of the Black Exodus story of liberation by saying:

Let us remember that as we struggle against Egypt, we must have love, compassion, and understanding goodwill for those against whom we struggle, helping them to realise that as we seek to defeat the evils of Egypt we are not seeking to defeat them but to help them, as well as ourselves. (King 1992:III, 261)

Now King is saying that his hearers do not want to defeat their evil enemies but want to 'help them'. More than that, his hearers will have to have 'love, compassion, and understanding goodwill' for those who have oppressed them. This is obviously not the expected end to the typical, typological understanding of the Black Exodus. Now even the evil enemies seem to be able to be fully included into God's side of good, which certainly makes the traditional typological understanding of the Exodus story pretty unreliable; for the latter understanding sees evil's ultimate doom at the seashore (again unless there is repentance from the latter). Yet, as said before, it is not that King's argument operates totally outside of the typological frame of the Exodus story. He retains a similar typological narrative form and tone to that of the Black church. Yet, at the same time, he subverts the fundamental ethos and pathos of that understanding, thus generating an other-typological interpretation.

For King, this sudden and explicit break from the traditional, typological story line is inevitable because of one fundamental theological reason; King recognises reconciliation between 
the two opposing sides as the ultimate socio-theological end of the Black people's struggle against all kinds of social evil. He says in his own words in the sermon:

God has a great plan for this world. His purpose is to achieve a world where all men will live together as brothers, and where every man recognises the dignity and worth of all human personality. (King 1992:III, 262)

The typical typological understanding of the Exodus story cannot convey this message as King intends because that traditional understanding primarily seeks for liberation of the Black oppressed, but not necessarily for a grand and general reconciliation which King firmly holds as a higher goal to be achieved.

For King, this ultimate, urgent reconciliation is possible and indeed desired because of his particular theological understanding of humanity, or more specifically evil-doers; his particular theological anthropology that is very different from the counterpart found in the traditional typological narrative of the Exodus story. In the latter Black Exodus narrative, the evil of the universe very much equals the evildoers of slavery. There is no separation between the two, apparently. So, as the universal evil must be defeated, the evil-doers must be utterly crushed because both are the same. By contrast, in King's theological anthropology that we see in his sermon, evil-doers are not perceived as evil itself; rather, they are ignorant victims or unfortunate counter-slaves captive in the universal evil scheme. Thus, while the universal evil must be defeated, the unfortunate white evil-performers must be freed and liberated as well. In short, the evilperformers themselves are not the evil objects doomed to annihilation. Besides, the prerequisite for the reconciliation is not repentance of ignorant victims (which will follow later), but 'exorcism' of the cosmic evil that hovers over their heads and minds.

In sum, as a good student of the Black tradition of the typological Exodus understanding, King initially absorbs the tradition's typological ethos and pathos in its full sense; the evil against the Black liberation must be defeated. By changing the very face of evil itself, however, King generates a new, different typological perception of the same story that I would like to call other-typology. Yes, the evil of the contemporary Egypt and Pharaoh must be defeated, but the evil is not the White America itself (or White people), but the universal social illness that permeates the American soil. King believes that when this social evil is defeated, there must be a grand reconciliation between the oppressed (Black people) and the oppressors (White people).

\section{Towards the Exodus illustration, theological-rhetorical}

This section examines how King, in light of his novel understanding of the Exodus typology, uses the story as a best available illustration to support the reconciliatory point of his sermon message. In other words, we will see that King is utilising the Exodus story as the best case to present the key sermon point clearly and persuasively; in so doing, the old familiar Exodus story ceases to be the traditional typological story of Black life now and then. As we will see, however, this illustrative use of the Exodus story is only possible because King invents the other-typological understanding of the story first.

In order to see how King utilises the Exodus story as a good illustration of the sermon point, we need to get an overview of the entire sermon and outline its flow as since the story appears as a critical illustrative part of the sermon. ${ }^{12}$ The basic literary scheme of the sermon is as follows:

1. Evil is present in the universe.

2. The Bible affirms the reality of evil.

3. Our everyday life also confirms the reality of evil.

4. In a sense, the whole history of life is the history of a struggle between good and evil.

5. But, the Hebraic Christian tradition, such as Christ's resurrection, affirms the ultimate doom of evil.

6. The Exodus story is also a graphic example of the final triumph of good over evil, Egypt being the symbol of doomed evil and Israel the victorious one of goodness.

7. Contemporary examples like the Civil Rights movement also reveal the ultimate victory of good.

8. This cosmic spiritual reality of ultimate good will eventually transform all corrupt people's minds that are captured in evil's universal scheme.

9. God's great plan for a world where all men will live together as brothers is the Kingdom of Christ.

As is explicit in the outline, the sermon starts with a general statement about the cosmic evil's presence in the universe and then enumerates two areas or examples in which that statement is affirmed. The second point is that the Christian tradition demonstrates the ultimate doom of evil and the victory of universal good, and three illustrations undergird this point: Christ's resurrection, the Exodus story, and the contemporary Black struggle. The sermon ends with the third point; God has a plan for a reconciled world following the utter defeat of evil, in which all people, including even former oppressors, will join one another as one divine family. Here, King is clear that this third point of the sermon is his ultimate vision of the world that he wants others to share as their own new Christian vision, story, and future faith identity for the realisation of the reconciled reality of the world.

The Exodus story, to which our research focus goes, therefore, appears in the sermon as the second illustration of the second sermon point - the cosmic struggle between good and evil, and the final doom of the latter and the victory of the former. However, neither is this second sermon point the ultimate

12. My sermon analysis method partly resonates with the Heidelberg method of sermon analysis, which Johan Cilliers (2006:11-13) adopts in his analysis of sermon analysis, which Johan cilly (2006:11-13) adopts in his analysis of sermons produced during the apartheid period in South Africa. The particular merits of this method are that: (1) it analyses the sermon both as a whole and according to meaning blocks; (2) it attempts to see explicit and implicit signs of languages in the sermon; (3) it explores what particular characteristics of God are revealed in the sermon; and (4) it interrogates how the biblical text is used in the making of situational analogy between the present and the biblical time. I utilise these four (and more) merits in my analysis of King's sermon. 
message nor can the Exodus story itself convey what King ultimately wants to proclaim. Simply put, the victory of one side and the doom of the other is not what King eventually seeks; King wants more than that. King, thus, pictures the second sermon point along with its illustrations as a penultimate or prerequisite stage toward the final, more glorious stage of the reconciled world of which he dreams. Going back to the question of the Exodus story itself, therefore, it is obvious that at its best, the story remains an important illustration of the second sermon point but not a traditional typological narrative on which the whole sermonic story line would be based. King himself affirms this in his own words:

A graphic example of this truth is found in an incident in the early history of the Hebrew people ... Egypt was the symbol of evil in the form of humiliating oppression, ungodly exploitation and crushing domination ... This story symbolises something basic about the universe. It symbolises something much deeper than the drowning of a few men, for no one can rejoice at the death or the defeat of a human person. This story, at bottom, symbolises the death of evil. It was the death of inhuman oppression and ungodly exploitation. (King 1992:III, 259-260)

King realises that the Exodus story itself symbolises or exemplifies a deeper truth that is bigger than what the story itself tells us in a literal or (traditional) typological sense. In other words, at this point, the Exodus story functions as a critical illustration which points to what the sermon ultimately argues for as 'something [truthful]in the very nature of the universe' (King 1992:III, 260). In short, King uses the Exodus story along with other illustrations besides with the literary goal of establishing a good basis for the bigger vision of the defeat of the evil itself and a reconciled world, a vision that goes beyond any simple theme of Exodus-liberation from the slavery or socio-political bondage.

Nonetheless, a reasonable question still lingers unresolved around at this point. Why do the readers of King, such as Lischer (1995:202-212), a phenomenal researcher of King's preaching, still mistakenly think that King was utilising the Exodus story in a traditional typological sense, even though he was not? Of course, a probable answer has been given in the previous section that King invents a new, different typology; people tend to take this different typology as the same as the traditional one. Yet, a couple of particular literary or theological-rhetorical techniques demonstrated in the sermon provide other good reasons to respond to this question as well.

Firstly, it is because although the Exodus story does not function at all in the sermon as a traditional typological narrative, it still supplies significant symbolic or metaphoric language through which the final sermon point is made. This is particularly true as the sermon approaches its end when King preaches:

[God] is seeking at every moment of His existence to lift men from the bondage of some evil Egypt, carrying them through the wilderness of discipline, and finally to the promised land of personal and social integration. (King 1992:III, 260)
In this short statement, there are three important symbols or metaphors working effectively and persuasively: Egypt, wilderness and the promised land. Once again, it should be clear that although it seems to, this statement in fact does not come up out of the typical typological understanding of the Exodus story. Instead, the ultimate vision of the reconciled world in the statement comes from King's other-typological reconstruction of the story. That being confirmed, it can be said that just as King recognises in the sermon, Egypt symbolises the evil of the universe while wilderness and the promised land metaphorically represent the continuing struggle between good and evil and the reconciled world, respectively. ${ }^{13}$ Throughout the sermon, especially in the second sermon point about Black Exodus liberation, this symbolic language and similar metaphoric expressions are strong enough to generate the reasonable impression of King's traditional typological understanding of the Exodus narrative, as if King were exclaiming, 'This story is just like our story!' Yet, as we know now, that Exodus story is not what King depicts as his ideal or his own faith story. The ideal is something else. Thus, King is not prone to accept the Exodus story itself as his own faith identity. At least, however, for King, the Exodus symbolism and related metaphoric expressions are the most, if not best, effective and persuasive literary tools with which to coin his novel theological ideas that are acceptable to his people, who traditionally and perhaps too easily have been identified with the typological Exodus narrative itself. Indeed, that is how good symbols and metaphors work in literature in general: the generation of a new reality or novel concept of the world through the familiar linguistic or narrative concepts (Lakoff \& Johnson 2003:3-6).

Secondly, King's illustrative interpretation of the Exodus story sounds highly traditional-typological, although it is not, because King first approaches the Exodus story from a cosmic perspective and then applies ethical dimensions of the story to the contemporary world and beyond. Thus, on the surface, it seems that King is identifying the Black church's contemporary earthly struggle with that of ancient Israelites in Exodus. But, again, this typological understanding of King's use of the Exodus story cannot do full justice to King himself. King, with a different typological and theological ideal that does not originate from the traditional interpretation of the same story, overcomes the theological limit of the story's ethical lesson. For King, the Black church's struggle or its ultimate purpose should be something far beyond the 'earthly' resolution between the oppressed and the oppressing reality.

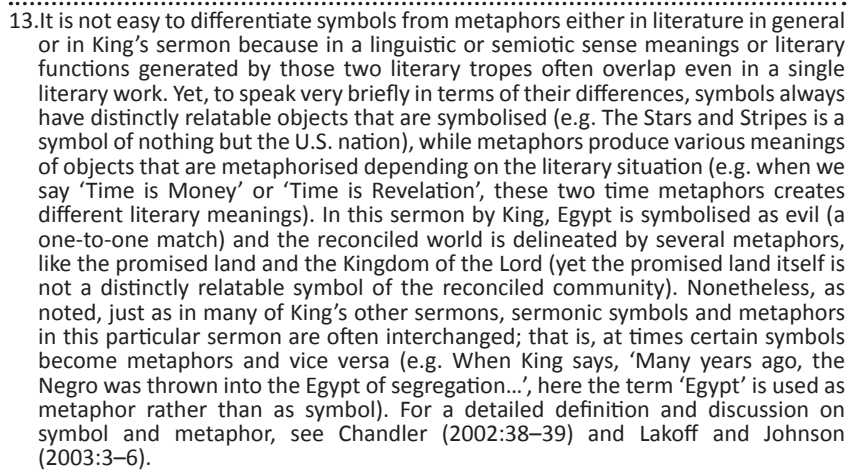

It is not easy to differentiate symbols from metaphors either in literature in genera or in King's sermon because in a linguistic or semiotic sense meanings or literary functions generated by those two literary tropes often overlap even in a single iterary work. Yet, to speak very briefly in terms of their differences, symbols always have distinctly relatable objects that are symbolised (e.g. The Stars and Stripes is a symbol of nothing but the U.S. nation), while metaphors produce various meanings of objects that are metaphorised depending on the literary situation (e.g. when we sime is Money" or "Time is Revelation', these two time metaphors creates

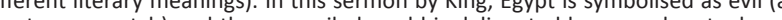
one-to-one match) and the reconciled world is delineated by several metaphors, 作 in this particular sermon are often interchanged; that is, at times certain symbols ( . symbol and metaphor, see Chandler (2002:38-39) and Lakoff and Johnson (2003:3-6). 


\section{Conclusion}

King's invention of the different typological or other-typological understanding of the Exodus story therefore leads to the illustrative use of the same story at a certain point of the sermon. Or the inverse is true. Because King wants to use the Exodus story as an excellent illustration only for the smaller or preparatory point of the sermon (King has another ultimate point of the sermon), the new typological understanding of the same story was inevitable for the continuing symbolic or metaphoric use of the story up until the end of the sermon. All this different typology of the Exodus story and its illustrative use of King arise from his own theological ideal and worldview that the original typological interpretation of the story cannot provide; namely, the victory of universal good over cosmic evil and the resulting reconciliation of all humanity.

\section{Acknowledgements Competing interests}

The author declares that he has no financial or personal relationships which may have inappropriately influenced him in writing this article.

\section{References}

Baer, H. \& Singer, M., 2002, African American religion: Varieties of protest and accommodation, University of Tennessee Press, Knoxville, TN.

Binckes, R., 2013, The Great Trek Uncut: Escape from British Rule: The Boer Exodus from the Cape Colony 1836, $30^{\circ}$ South Publishers (Pty) Ltd, Pinehill, South Africa.
Carson, C., Luker, R. \& Russell, P.A. (eds.), 1992, The papers of Martin Luther King, Jr. University of California Press, Berkeley, CA.

Chandler, D., 2002, Semiotics: The basics, Routledge, London.

Cilliers, J., 2006, God for us: An analysis and assessment of Dutch Reformed preaching during the apartheid years, Sun Press, Stellenbosch.

Cone, J.H., 2000, The spirituals and the blues: An interpretation, Orbis Books, Maryknoll, NY.

Craddock, F.B., 1985, Preaching, Abingdon Press, Nashville, TN.

Jones, I.T., 1956, Principles and practice, Abingdon Press, Nashville, TN.

Lakoff, G. \& Johnson, M., 2003 [1980], Metaphors we live by, The University of Chicago Press, Chicago, IL.

LaRue, C.J., 1999, The heart of black preaching, Westminster John Knox, Louisville, KY.

Lincoln, C.E. \& Lawrence H.M., 1990, The black Church in the African-American experience, Duke University Press, Durham.

Lischer, R., 1995, The Preacher King: Martin Luther King Jr. and the Word that Moved America, Oxford Press, New York.

Livermore, M.A., 1888, My story of the war: A woman's narrative of four years personal experience as nurse in the Union Army, and in relief work at home, in Hospitals, Camps, and at the front during the War of Rebellion. With anecdotes, pathetic incidents and thrilling reminiscences portraying the lights and shadows of hospital life and the Sanitary Service of the War, A.D. Worthington \& Co., Hartford, CT.

Long, T.G., 1989, The witness of preaching, Westminster John Knox Press, Louisville, KY.

Mays, B.E., 1969, The Negro's God, as reflected in his literature, Negro Universities Press, New York.

Mitchell, H.H., 1990, Black preaching: The recovery of a Powerful Art, Abingdon Press, Nashville, TN.

Patte, D., 2010, The Cambridge Dictionary of Christianity, Cambridge University Press, New York.

Proctor, S.D., 1994, The certain sound of the trumpet: Crafting a sermon of authority, Judson Press, Valley Forge, PA.

Raboteau, A.J., 1995, A fire in the bones, Beacon Press, Boston, MA.

Sanster, W.E., 1954, The craft of the sermon, Epworth Press, London.

Sweazey, G.E., 1976, Preaching the Good News, Prentice-Hall, Englewood Cliffs, NJ.

Woodson, C.G. (ed.), 1942, The works of Francis J. Grimke, vol. 1: Addresses mainly Personal and Racial, Associated Publishers, Washington, DC. 